\title{
Power management strategy based sugeno fuzzy logic rules in an electric wheelchair
}

\author{
Chakar Abdeselem', Abdelkhalek Othmane ${ }^{2}$, Gasbaoui Brahim $^{3}$, Soumeur Mohammed Amine ${ }^{4}$, \\ Hafsi Oussama ${ }^{5}$, Hartani Mohammed Amine ${ }^{6}$ \\ ${ }^{1-5}$ Smart Grids and Renewable Energies Laboratory SGRE, University of Tahri Mohamed, Bechar, Algeria \\ ${ }^{6}$ Laboratory of durable development and informatics LDDI, University of Ahmed Draia, Adrar, Algeria
}

\section{Article Info}

Article history:

Received Dec 24, 2020

Revised Feb 15, 2021

Accepted Mar 13, 2021

Keywords:

DC-DC converter

Electrical wheelchair

Fuzzy logic controller

Power management

PVsystem

\begin{abstract}
Power management in multi-power supply electrical systems to manage the general system behavior is essential to improve autonomy and efficiency. In this paper, a proposed fuzzy-logic power management-based sugeno rule is applied in a hybrid PV/battery electric wheelchair to ameliorate the battery life cycle and the overall autonomy. Besides, the increment conductance INC MPPT is used to maximize PVpower. The electric wheelchair's general topology comprises photovoltaic energy resources as the main source and the battery energy storage system device as the auxiliary source. This hybrid power source system supplied the electric wheelchair composed two permanent magnet DC motors controlled by a PI controller. MATLAB/Simulink program is used to implement the overall control scheme. The simulation results that were obtained and the detailed study demonstrate the feasibility and performance of this intelligent strategy.
\end{abstract}

This is an open access article under the CC BY-SA license.

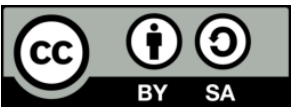

\section{Corresponding Author:}

Chakar Abdeselem

Laboratory of Smart Grids and Renewable Energies SGRE-L

Electrical Engineering Department

Tahri Mohamed University

The independence street, PB 417 Bechar, Algeria

Email: chakar.abdeselem@univ-bechar.dz

\section{INTRODUCTION}

Since its inception, electric wheelchairs [1] have made a significant improvement in the lives of person have a disability because it gave them the freedom to move on their own without relying on others [2], the wheelchair control system includes two electrics motors associated with drive electronics used in powering electric wheelchairs. The wheelchair can use any motor technology such as permanent magnet DC motors or brushless DC motors. Input, such as a joystick or Camera used as a user [3], [4], joystick permits the entry of commands controlling the speed and direction of the electric wheelchair.

With the progress of time, the handicapped person starts to complain about the limited batteries. This last, takes a long time to charge in further it takes less time to discharge with no charging places in roads, and this is what prompted many researchers to find new ways to feed motors, whether developing batteries in terms of autonomy and performance [5] or terms of cycle life [5]. In other words, others decided to find other sources to support the battery, such as integrating solar panels [2], [7], [8] or integrating a fuel cell [8]-[10] to support the battery and give disabled people more freedom of movement.

In this paper, we integrate a solar panel with keeping the battery to feed two wheelchair motors, and because the motor is not of the same type, we connected both generators via DC-DC boost converter 
controlled by INC MPPT for optimum exploitation [11], [12]. The battery is connected to a bidirectional DCDC converter for controlling charging and discharging using a PI controller.

The desired goal is to protect the battery against working in deep of discharge and state of charge maximal under all the moving phases of the wheelchair, we adopted a power management strategy based on sugeno fuzzy logic, so that the input of the fuzzy logic control is state of charge of the battery and the different power between the PVand the power required by two wheelchair motors. Simultaneously, the outputs are the orders directed to each of the drive electronics elements for the chair, the PV, and the battery.

This paper is divided into five sections. The first section gives a brief description of the electric wheelchair and supplies power system, the second section modeling, and sizing of the global system, the methodology of power management and how to used sugeno fuzzy logic controller is outlined in the third section, the fourth section gives the results and discussions of our work. In the end, some of our conclusions are drawn in the final section.

\section{ELECTRICAL WHEELCHAIR DESCRIPTION}

The wheelchair general configuration consists of two independent DC parament magnetic motors to ensure the driving of wheels, speed, and steering angle are controlled using an electronic differential to calculate the speed for each wheel and regulate it with PI control motor has a DC-DC buck converter. The propulsion system supplied by the PVsystem, as the primary source the photovoltaic panel connected to DC bus voltage via a DC-DC boost converter controlled by the increment conductance maximum power tracking (MPPT) and the secondary source is the battery storage connected to the DC bus voltage via a DC-DC bidirectional buck-boost converter [2], [13]. This hybrid energy source is managed by a proposed fuzzy-logic power management based sugeno rules, described in Figure 1. Tables 1 and 2 show the wheelchair model and parameters that were used.

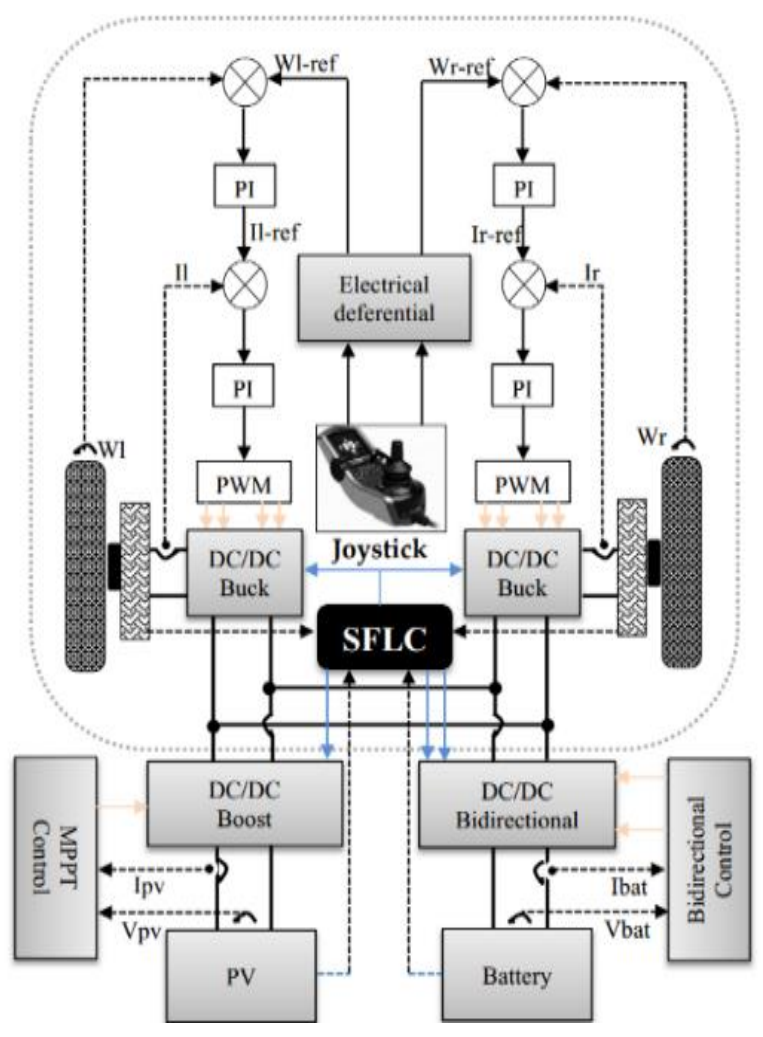

Figure 1. The proposed system of the wheelchair and power sources (PV-Battery) with power management

\section{MODELLING OF ELECTRICAL WHEELCHAIR WITH POWER SUPLLY GENERATOR}

\subsection{Electrical wheelchair model}

The power of an electric wheelchair depends on the type of battery, the overall wheelchair weight, the terrain, and the efficiency of the control system. Batteries are rated hourly ampere [14]. The current determines the total distance of the electric wheelchair, while the amount of current absorbed is related to the 
torque applied to the wheelchair motors. According to Figure 2, the mechanical module of the wheelchair is based on the forces of opposition acting against it, Where the total resistive torque is given by.

The $T_{r r}$ torque rolling resistance is defined by.

$$
T_{r r}=M g C_{x} \cos (\alpha) \cdot R_{w}
$$

The aerodynamic drag force $T_{\text {aero }}$ is given as.

$$
T_{\text {aero }}=\frac{1}{2} \rho_{\text {air }} A C_{d} V_{w}^{2} R_{w}
$$

The climbing force of the hill $T_{c}$

$$
T_{c}=\operatorname{Mg} \sin (\alpha) \cdot R_{w}
$$

The force associated with the $T_{a c c}$ acceleration is

$$
T_{a c c}=M \gamma R_{w}
$$

Total torque $\mathrm{T}$ w calculated as follows in electric cars [15], [16]

$$
T_{w}=\frac{1}{2} \rho_{a i r} A C_{d} V_{w}^{2} R_{w}+M g C_{x} \cos (\alpha) \cdot R_{w}+ \pm M g \sin (\alpha) \cdot R_{w}+M \gamma R_{w}
$$

The wheelchair motor used model parameters are illustrated at the following Table 1, and in the Table 2 parameter of the electrical wheelchair used in this work.

Table 1. The parameter of permanent magnet

\begin{tabular}{ccccc}
\hline Model number & Operation voltage(v) & Output power(w) & No-load output speed (rpm) & No-load current(a) \\
\hline dg-168a & 24 & 150 & 135 & $<=4,5$ \\
\hline
\end{tabular}

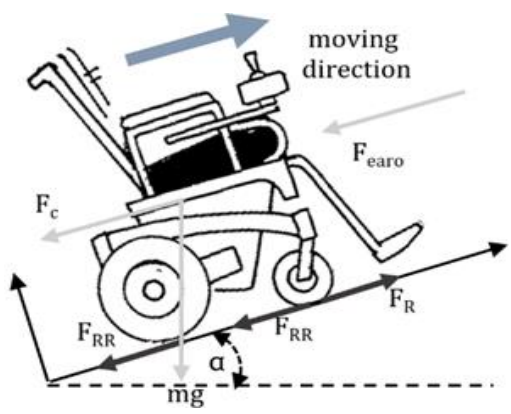

Figure 2. Forces exerted on the electric wheelchair

Table 2. The parameter of electrical wheelchair

\begin{tabular}{cccccccc}
\hline Symbole unit & $\boldsymbol{M}(\mathrm{Kg})$ & $\boldsymbol{C}_{\boldsymbol{d}}\left(\mathrm{S}^{2} / \mathrm{M}^{2}\right)$ & $\boldsymbol{\rho}_{\text {air }}\left(\mathrm{Kg} \cdot \mathrm{M}^{3}\right)$ & $\boldsymbol{A}\left(\mathrm{M}^{2}\right)$ & $\boldsymbol{R}_{\boldsymbol{w}}(\mathrm{M})$ & $\boldsymbol{C}_{\boldsymbol{x}}$ & $\boldsymbol{g}\left(\mathrm{M} / \mathrm{s}^{2}\right)$ \\
\hline Values & 150 & 0.013 & 1.109 & 0.7 & 0.16 & 0.31 & 9.8
\end{tabular}

Where $M(\mathrm{~kg})$ is total mass, $C_{d}$ is tire rolling resistance coefficient $(\mathrm{s} 2 / \mathrm{m} 2), \rho_{\text {air }}$ is mass density of air $(\mathrm{kg} / \mathrm{m} 3) ; A$ is frontal surface area of the wheelchair(m2), $R_{w}$ is wheel $\operatorname{radius}(\mathrm{m}), C_{x}$ is aerodynamic drag coefficient and $g(\mathrm{~m} / \mathrm{s} 2)$ is acceleration due to gravity.

\subsection{The photovoltaic module}

An equal with series and parallel resistors, an ideal current source can be developed. may be used to reflect a photovoltaic source. [17], which directly convert sunlight into electricity [18], the output current of the PVdescribes in (6), the PVmodule out put used in the Table 3 where tow panel are instqlled parallel [19], [20].

$$
\mathrm{I}_{\mathrm{pv}}=\left(\mathrm{I}_{\mathrm{pv}, \mathrm{N}}+\mathrm{K}_{\mathrm{I}} \cdot \Delta_{\mathrm{T}}\right) \cdot \frac{\mathrm{G}}{\mathrm{G}_{\mathrm{n}}}
$$


Table 3. The PVmodule data-sheet

\begin{tabular}{ccccccc}
\hline Name & $\begin{array}{c}\text { MPP power } \\
(\mathrm{Pmpp})\end{array}$ & MPP voltage (Vmp) & MPP current (Imp) & $\begin{array}{c}\text { Open circuit } \\
\text { voltage (Voc) }\end{array}$ & $\begin{array}{c}\text { Short circuit } \\
\text { current (Isc) }\end{array}$ \\
\hline Ds-100m & $100 \mathrm{~W}$ & $18 \mathrm{~V}$ & $5.55 \mathrm{~A}$ & $21.24 \mathrm{~V}$ & 6.4 & $\mathrm{~A}$ \\
\hline
\end{tabular}

\subsection{Battery model}

Because of its long life, lithium-ion batteries have developed into an ideal power source for storing renewable energy. a high level of protection and a low cost [21]. The battery parametrs used shown in the Table 4. The charging scenario's battery terminal voltage concerning time is given in the (7) [22], [23].

$$
\mathrm{V}_{\mathrm{bc}}\left(\mathrm{t}_{\mathrm{c}}\right)=\left(\left(\frac{\mathrm{Q}}{\mathrm{C}}+\mathrm{I}_{\mathrm{C}} \times \mathrm{R}_{2}\right) \times \exp \left(-\frac{\mathrm{t}_{\mathrm{c}}}{\mathrm{R}_{2} \times \mathrm{C}_{1}}\right)\right)+\mathrm{V}_{0}-\left(\left(\mathrm{I}_{\mathrm{C}}-\left(\mathrm{R}_{1}+\mathrm{R}_{2}\right)\right)\right)
$$

Similarly, for a discharging scenario, the battery terminal voltage is given in (8).

$$
\mathrm{V}_{\mathrm{bd}}\left(\mathrm{t}_{\mathrm{d}}\right)=\left(\left(\frac{\mathrm{Q}}{\mathrm{C}}+\mathrm{I}_{\mathrm{d}} \times \mathrm{R}_{2}\right) \times \exp \left(-\frac{\mathrm{t}_{\mathrm{d}}}{\mathrm{R}_{2} \times \mathrm{C}_{1}}\right)\right)+\mathrm{V}_{0}-\left(\left(\mathrm{I}_{\mathrm{d}}-\left(\mathrm{R}_{1}+\mathrm{R}_{2}\right)\right)\right)
$$

Table 4. Parameter of li-ion battery

\begin{tabular}{ccc}
\hline Type & nominal voltage (v) & nominal capacity (Ah) \\
\hline lead-acid & 12 & 28 \\
\hline
\end{tabular}

\section{POWER MANAGEMENT STRATEGY}

The power management system will help wheelchairs react more dynamically, and ameliorate their performance and autonomy without losing sight of the main goal that improves the battery life cycle and utilizing solar power [24]. Therefore, in this work, a proposed fuzzy-logic power management based sugeno rules are applied. The power management operation theory is based on a number of rules that are designed using various conditions such as battery state of charge (SOC), power load demand from wheelchair motors, and solar panel power. These conditions parameters are utilized to build management rules based on sugeno fuzzy logic to solve system behavior. The basic idea of this strategy that moving in different states in each state makes decisions. All these modes are built-in face membership's fuzzy logic rules, where the output decisions of this management are orders to command DC-DC converters.

The following flowchart Figure 3 describes the proposed general system power management strategy, which aims to control the battery when it charges or discharges [25]. The most important thing is to protect the battery in critical conditions and use the solar panel's maximum power, where there are four modes to supervise the system behavior.

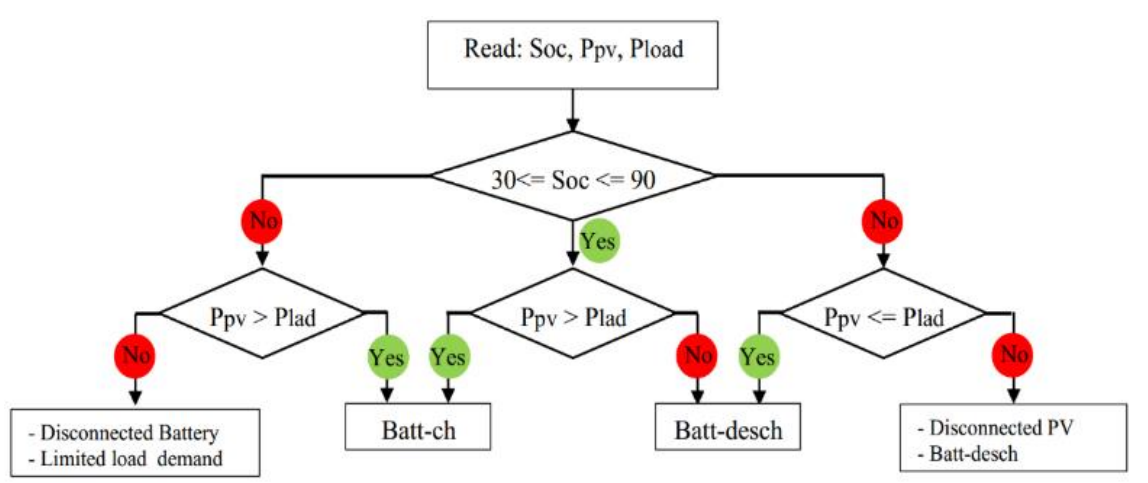

Figure 3: The proposed management strategy flowchart

The strategy illustrated Sugeno fuzzy logic controller was used to incorporate the previous part. A fuzzy logic controller relates the controller outputs to inputs using a list of if-then [26] see Table 5. The 
adjectives that characterize regions of the input variable are referred to in the if-part of the rules. The degree to which a given input value belongs to these regions is defined by the degree of membership. The then part of the rules of a sugeno fuzzy logic controller refers to values of the output variable on or off.

The subsets fuzzy membership was noted as follows, See the Figure 4 membership functions of input and output, i) SOC min: SOC less then 30\%; moy: SOC between $30 \%$ and $90 \%$; max: SOC under then $90 \%$, ii) $\Delta \mathrm{p}=\mathrm{Ppv}-\mathrm{P}_{\text {load }}$ ni: negative; null: $\mathrm{Ppv}=\mathrm{P}_{\text {load }}$; po: positive, and iii) $\mathrm{K}_{\mathrm{i}}$ higt: output=1; low: output=0. The implementation of this management strategy in MATLAB/Simulink fact by dc converter control where K1 is the switch for control the PVpanel, K21, K22 are charged and discharged battery and K3 for a motors load demand control.

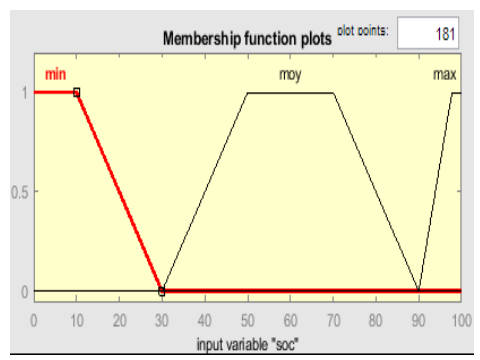

(a)

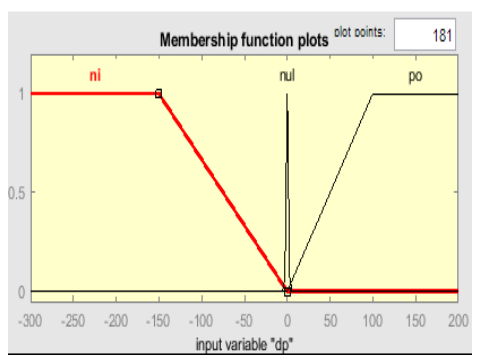

(b)

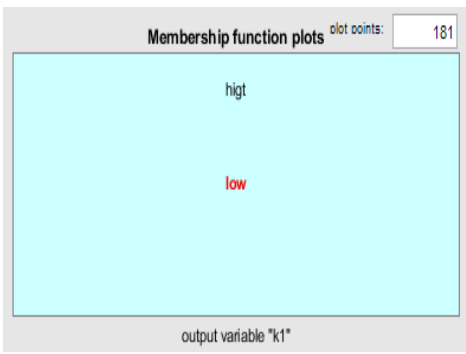

(c)

Figure 4. Input and output membership functions, (a) 'Soc'; (b) 'dp'; (c) 'K1, K21, K22, K3

Table 5. The rules base of fuzzy controller

\begin{tabular}{cllllll}
\hline$\Delta \mathrm{p}$ Soc & \multicolumn{2}{c}{$\mathrm{Ni}$} & \multicolumn{2}{c}{ Nul } & \multicolumn{2}{c}{ Po } \\
\hline \multirow{2}{*}{ Min } & $\mathrm{K} 1=1$ & $\mathrm{~K} 21=0$ & $\mathrm{~K} 1=1$ & $\mathrm{~K} 21=0$ & $\mathrm{~K} 1=1$ & $\mathrm{~K} 21=1$ \\
& $\mathrm{~K} 22=0$ & $\mathrm{~K} 3=1$ & $\mathrm{~K} 22=0$ & $\mathrm{~K} 3=1$ & $\mathrm{~K} 22=0$ & $\mathrm{~K} 3=1$ \\
\multirow{3}{*}{ Moy } & $\mathrm{K} 1=1$ & $\mathrm{~K} 21=0$ & $\mathrm{~K} 1=1$ & $\mathrm{~K} 21=0$ & $\mathrm{~K} 1=1$ & $\mathrm{~K} 21=1$ \\
& $\mathrm{~K} 22=1$ & $\mathrm{~K} 3=1$ & $\mathrm{~K} 22=0$ & $\mathrm{~K} 3=1$ & $\mathrm{~K} 22=0$ & $\mathrm{~K} 3=1$ \\
\multirow{2}{*}{ Max } & $\mathrm{K} 1=1$ & $\mathrm{~K} 21=0$ & $\mathrm{~K} 1=1$ & $\mathrm{~K} 21=0$ & $\mathrm{~K} 1=0$ & $\mathrm{~K} 21=0$ \\
& $\mathrm{~K} 22=1$ & $\mathrm{~K} 3=1$ & $\mathrm{~K} 22=0$ & $\mathrm{~K} 3=1$ & $\mathrm{~K} 22=1$ & $\mathrm{~K} 3=1$ \\
\hline
\end{tabular}

\section{RESULTS AND DISCUSSION}

Simulating the model was achieved using the MATLAB Simulink program in this section, and the obtained findings are presented and discussed in order to check the serviceability and performance of the proposed method. during a time, simulation of $24 \mathrm{~s}$. The solar irradiance and temperature for the PVwere simulated with a constant temperature under STC $25^{\circ}$ and a specified irradiance profile.

The wheelchair has been designed to be indicative of real dynamic working conditions, with the wheelchair traveling on straight roads with a maximum speed of $7 \mathrm{~km} / \mathrm{h}$ and a minimum speed of $1.5 \mathrm{~km} / \mathrm{h}$, moving on a slope [16:17.5] (s) and curved road [21: 22.5] (s), which is defined by different constant [0.5:2.5] (s), accelerating [0:5] (s), and braking time intervals [2.5: 3.5] s. For the battery SOC, we impose that the battery is one under 30\% [6:7.5] (s) and above 90\% [11:12.5] (s) to ascertain the system behavior. Thus, Figure 5 is displaying the reference and motor speeds during the domestic cycle simulation.

The wheelchair's speed is approximately equal to its reference value, which is calculated as the mean value of the two wheal's speeds, as shown in Figure 5. We've noticed that variations in the degree of feeding have no effect on the wheelchair's speed, and that the presence or absence of sun irradiance [0-1.5] (s) and the battery state of charge as in the interval [6-7.5] (s), $[11,12.5]$ (s) has no effect on the wheelchair's speed. During the interval [16-17.5] (s), the wheel's speed was kept constant at $3 \mathrm{~km} / \mathrm{h}$ despite the increase of the road slope angle alpha. in addition, between [21-22.5] (s), we notice a difference between the speeds of the two wheels due to the role of the differential electronic's role at the corners, which keep the speed stable. A pi controller regulates the speed error between the reference value of the electrical deferential and the operating speeds of each wheel to obtain the reference current value, which is then regulated by a second pi controller to produce sufficient PWM signals to each wheel motor's DC-DC buck converter.

As shown in this section, the power balance evaluation of PV/load/battery of the whole system is presented in the Figure 6. The change in battery power Pbat is determined by the amount of energy supplied by the solar panel and the amount of energy required by the load when the battery system is discharged. When PPV> Pload, the PVpanels supply not only the load but also the excess power produced by the PVpanels, which is used to charge the battery. 


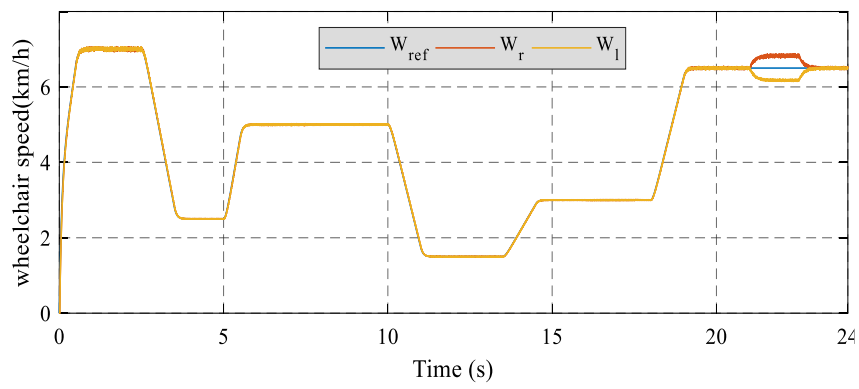

Figure 5. Reference and motor speeds during the domestic cycle simulation

So, at the start, just the battery supplies the electric wheelchair due to the absence of PVpower. Then, at the 1s the battery begins to discharge because the PVpanel starts to give the constant power and the required power by wheelchair discharge. At the interval [4.1-5.5] (s), the battery charges due to the PVpower is more significant than the wheelchair required power.

The battery is disconnected and the wheelchair is powered by luck power (limited load demand) in the interval [6-7.5] (s), the battery state of charge is less than 30\%, and the wheelchair needed power is greater than PVprovided power, so the battery is disconnected and the wheelchair is powered by luck power (limited load demand). The PVpower is greater than the required power, so the PVis disconnected, and the battery is discharged.

The electric wheelchair DC bus voltage is shown in Figure 7 which we have seen the DC bus voltage follows the reference under all the moving phases with overshoot of 2 volt, with ripple almost negligible and response time is 0.2 (s). Just in the case when the battery is disconnected, the DC bus voltage drops by 3 volts. As seen, during the proposed cycle and the evaluation of the power. In the Figure 8 The state of charge is increasing when $\mathrm{P}_{\mathrm{pv}}>\mathrm{P}_{\text {load }}$ which mean that the battery is absorbing the surplus energy during [4.5-5.5] (s) and [11-16] (s), the SOC decreasing when P Pvless than $\mathrm{P}_{\text {load }}$ (discharge) [0-4.5] (s), [7.5$11]$ (s), and the battery is disconnected between 6 and $7.5(\mathrm{~s})$.

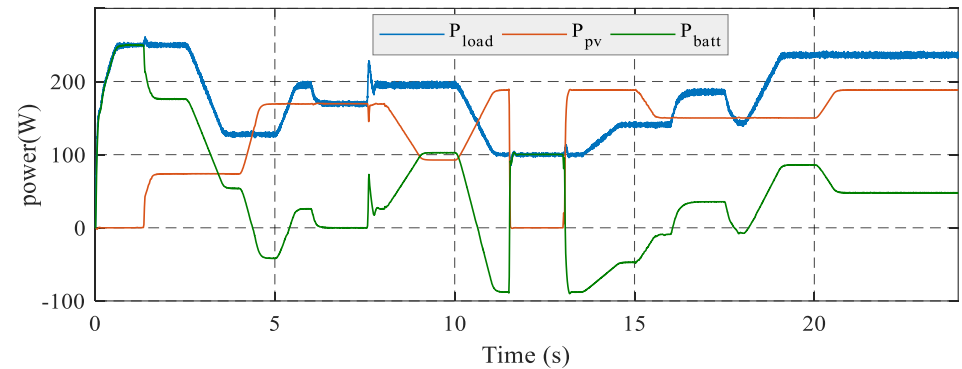

Figure 6. The power balance profile of PV/load/battery

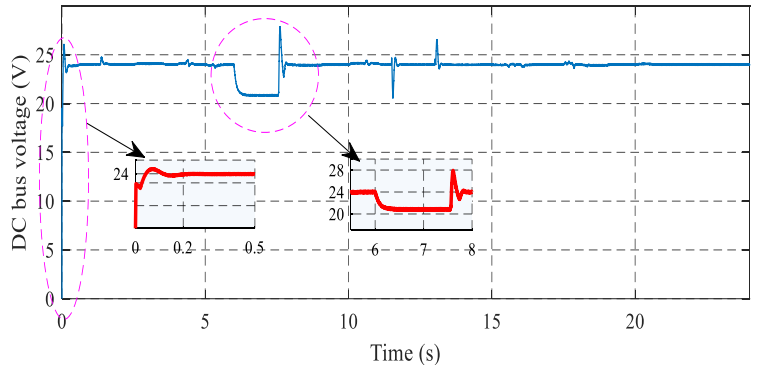

Figure 7. The DC-bus voltage during the domestic simulation cycle

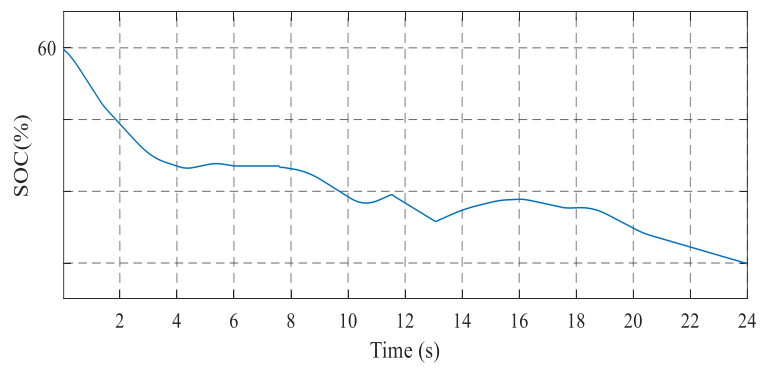

Figure 8. Battery state of charge 


\section{CONCLUSION}

This paper proposes an efficient system for managing power based on SOC, the power balance of the system load demand, and solar-generated power for managing the charge-discharge of battery the Moreover protected the battery in the critical case, that uses the fuzzy logic controller (FLC) for adjusting the general behavior of the system. The fuzzy rules are formed based on sugeno that help to have a best efficecy and incrase the wheelchair autonomy. Also, the hybridation between the battery and PVgives a good combinaton, extracting the max power used MPPT, fast response and the best beneficiation that makes the system stable.

\section{ACKNOWLEDGMENTS}

The writers gratefully accept the PRFU project's financial support from the General Direction of Scientific Research and Technological Advancement, DGRSDT (n 080120180002).

\section{REFERENCES}

[1] Ahmad Rifai Sarraj and Raphael Massarelli, "Design history and advantages of a new lever-propelled wheelchair prototype," International Journal of Advanced Robotic Systems, vol. 8, no. 3, pp. 12-21, 2011, DOI: DOI.org/10.5772/10669.

[2] Arun Manohar Gurram, P.S.V. Ramana Rao, and Raghuveer Dontikurti, "Solar powered wheel chair: Mobility for physically challenged," International Journal of Current Engineering and Technology, vol. 2, pp. 211-214, 2012.

[3] Yassine Rabhi, Makrem Mrabet, and Farhat Fnaiech, "Intelligent control wheelchair using a new visual joystick," Journal of Healthcare Engineering, vol. 2018, no. 3, pp. 1-20, 2018, DOI: 10.1155/2018/6083565.

[4] Dulari Sahu, "Automatic camera-based eye controlled wheelchair system using raspberry Pi," International Journal of Science, Engineering and Technology Research (IJSETR), vol. 5, no 1, pp. 364-368, 2016.

[5] D. A. Martinez, J. D. Poveda, and D. Montenegro, "Li-Ion battery management system based in fuzzy logic for improving electric vehicle autonomy," 2017 IEEE Workshop on Power Electronics and Power Quality Applications (PEPQA), IEEE, 2017, pp. 1-6, DOI: 10.1109/PEPQA.2017.7981677.

[6] Xuebing Han, Languang Lu, Yuejiu Zheng, Xuning Feng, Zhe Li, and Jianqiu Li, "A review on the key issues of the lithium ion battery degradation among the whole life cycle," eTransportation, vol. 1, p. 100005, 2019, DOI: 10.1016/j.etran.2019.100005.

[7] Chi-Sheng Chien, Tung-Yung Huang, Tze-Yuan Liao, Tsung-Yuan Kuo, and Tzer-Min Lee, "Design and development of solar power-assisted manual/electric wheelchair," Journal of Rehabilitation Research \& Development, vol. 51, vol. 49, pp. 1411-1426, 2014 DOI: 10.1682/JRRD.2013.11.0250.

[8] Yoshihiko Takahashi, and Syogo Matsuo, "Running experiments of electric wheelchair powered by natural energies," 2011 IEEE International Symposium on Industrial Electronics. IEEE, pp. 945-950, 2011, DOI: 10.1109/ISIE.2011.5984286.

[9] Kazuo Saito, Chan Anyapo, Pitak Kamjitjam, and Toshihiko Noguchi, "Development of an electric wheelchair system using PEM fuel cell," Journal of Asian Electric Vehicles, vol. 7, no. 1, pp. 1185-1190, 2009, DOI: 10.4130/jaev.7.1185.

[10] Dafne Zuleima Morgado Ramirez, et al., "Adjusted method to calculate an electric wheelchair power cycle: fuel cell implementation example," Journal of Energy Storage, vol. 23, pp. 371-380, 2019, DOI: 10.1016/j.est.2019.01.027.

[11] P. Vital Rao, K. R. Sudha, and S. Prameela Devi, "Incremental conductance (IncCond) algorithm for maximum power operating point (MPOP) of photo-voltaic (PV) power generation system," American Journal of Engineering Research (AJER), vol. 2, no. 12, pp. 334-342, 2013.

[12] H. Abouobaida, "Practical performance evaluation of maximum power point tracking algorithms in a photovoltaic system," International Journal of Power Electronics and Drive Systems (IJPEDS), vol. 8, no. 4, pp. 1744-1755, Dec. 2017, DOI: 10.11591/ijpeds.v8.i4.pp1744-1755.

[13] Peter, O., Muduli, K., Pumwa, J., Maryam, O., Tochukwu, N., and David, S. K., "Solar powered wheel chair for lower limb amputee," International Journal of Advanced Science and Technology, vol. 29, no. 7, pp. 369-377, 2020.

[14] Hartani M. A., Hamouda M., Abdelkhalek O., and Hafsi O, "Influence of MPPT technics and energy storage management on renewable hybrid power systems," Electrotehnica, Electronica, Automatica (EEA), vol. 67, no. 3, pp. 22-36, 2019.

[15] Md Ruhul Amin, and Rajib Baran Roy, "Determination of electric vehicle power consumption for assorted pavement gradient using Matlab/Simulink," Indonesian Journal of Electrical Engineering and Computer Science (IJEECS), vol. no.12, no. 9, pp. 6602-6611, Sept. 2014, DOI: 10.11591/ijeecs.v12.i9.pp6602-6611.

[16] Abdelkader Ghezouani, Brahim Gasbaoui, Nouria Nair, Othmane Abdelkhalek, and Jemal Ghouili, "Comparative study of PI and fuzzy logic-based speed controllers of an ev with four in-wheel induction motors drive," Journal of Automation Mobile Robotics and Intelligent Systems, vol. 12, pp. 43-54, 2018, DOI: 10.14313/JAMRIS_3-2018/17.

[17] Xuan Hieu Nguyen and Minh Phuong Nguyen, "Mathematical modeling of photovoltaic cell/module/arrays with tags in Matlab/Simulink," Environmental Systems Research, vol. 4, no. 1, pp. 24, 2015, DOI: 10.1186/s40068-0150047-9. 
[18] Otmane Zebraoui, and Mostafa Bouzi, "Improved MPPT controls for a standalone PV/wind/battery hybrid energy system," International Journal of Power Electronics and Drive Systems (IJPEDS), vol. 11, no. 2, pp. 988-1001, Jun. 2020, DOI: 10.11591/ijpeds.v11.i2.pp988-1001.

[19] Hafsi O, Abdelkhalek O, Hartani M. Amine, Chakar A, and Soumeur M. Amine, "Proposed energy management for a decentralized DC-microgrid based PV-WT-HESS for an isolated community," International Journal of Power Electronics and Drive System (IJPEDS), vol. 11, no. 4, pp. 2073-2082, Jun. 2020, DOI: 10.11591/ijpeds.v11.i2.pp988-1001.

[20] Hussain Attia, "High performance PVsystem based on artificial neural network MPPT with PI controller for direct current water pump applications," International Journal of Power Electronics and Drive Systems (IJPEDS), vol. 10, no. 3, pp. 1329-1338, Sept. 2019, DOI: 10.11591/ijpeds.v10.i3.pp1329-1338.

[21] Mostefa Kermadi, Zainal Salam, and El Madjid Berkouk, "A rule-based power management controller using stateflow for grid-connected PV-battery energy system supplying household load," 2018 9th IEEE International Symposium on Power Electronics for Distributed Generation Systems (PEDG). IEEE, 2018, pp. 1-6, DOI: 10.1109/PEDG.2018.8447566.

[22] Kannan Thirugnanam, Himanshu Saini, and Praveen Kumar, "Mathematical modeling of li-ion battery for charge/discharge rate and capacity fading characteristics using genetic algorithm approach," 2012 IEEE Transportation Electrification Conference and Expo (ITEC), IEEE, 2012, pp. 1-6, DOI: 10.1109/ITEC.2012.6243431.

[23] Praveen Kumar, and Pavol Bauer, "Parameter extraction of battery models using multi objective optimization genetic algorithms," Proceedings of 14th International Power Electronics and Motion Control Conference EPEPEMC 2010, pp. T9-106-T9-110, DOI: 10.1109/EPEPEMC.2010.5606653.

[24] Soumeur, M. A., Gasbaoui, B., Abdelkhalek, O., Ghouili, J., Toumi, T., and Chakar, A., "Comparative study of energy management strategies for hybrid proton exchange membrane fuel cell four wheel drive electric vehicle," Journal of Power Sources, vol. 462, Jun. 2020, DOI: 10.1016/j.jpowsour.2020.228167.

[25] Abitha Memala W, C. Bhuvaneswari, S. M. Shyni, G. Merlin Sheeba, Modi Surya Mahendra, and V Jaishree, "DCDC converter based power management for go green applications," International Journal of Power Electronics and Drive Systems (IJPEDS), vol. 10, no. 4, pp. 2046-2054, Dec. 2019, DOI: 10.11591/ijpeds.v10.i4.pp2046-2054.

[26] Chebel Ahlem, Benretem A, Dobrev I, and Barkat I, "Comparative study of two control strategies proportional integral and fuzzy logic for the control of a doubly fed induction generator dedicated to a wind application," International Journal of Power Electronics and Drive Systems (IJPEDS), vol. 11, no. 1, pp. 263-274, 2020, DOI: 10.11591/ijpeds.v11.i1.pp263-274.

\section{BIOGRAPHIES OF AUTHORS}

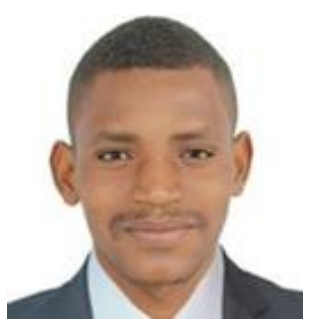

Chakar Abdeselem in 1992, he was born in Aougrout, Adrar, Algeria. He graduated from Djalili Liabes University in Sidi Bel Abbas, Algeria, with a degree in Electrical Engineering in 2014. He obtained a Master's Degree in Electrical System Control from the same university in Sidi Bel Abbas, Algeria, in 2016. He is currently a Ph.D. candidate at Tahri Mohammed University's smart grids and renewable energy laboratory. Electric wheelchairs, electric motors, DC-DC converters, power storage, PVnetworks, and DC micro-grids are among his research interests. E-mail : abdeselemchakar@gmail.com

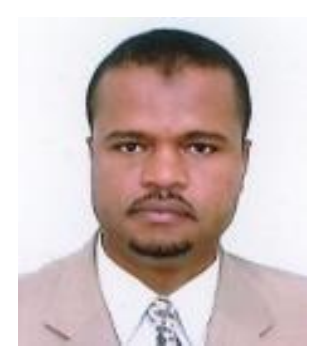

Abdelkhalek Othmane in 1976, he was born in Taghit, Bechar, Algeria. He holds an Eng. degree from Bechar University Center, a Magister's degree from Sidi-bel-Abbes University, and a Ph.D. from University of Bechar. He is currently Professor of Electrical Engineering at Bechar University. Power electronics, power efficiency, active filtering, DVR, UPQC, control, digital control, and load flow optimization are some of his research interests. Study on low-voltage DC micro-grids and renewable energy integration into island micro-grids. E-mail : othmane_elec@yahoo.fr

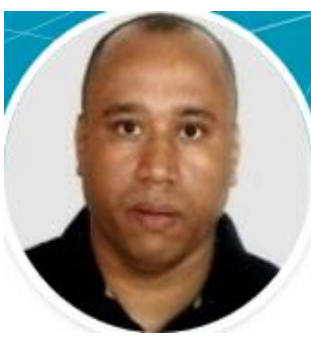

Gasbaoui Brahim, he obtained a degree in electrical engineering from Tiaret's IbnKhaldoun University in 1993, a master's degree from Bechar University in 2008, and a Ph. D. from Bechar University's Faculty of Science and Technology in 2009. He is currently a professor of electrical engineering at University of bechar. Power electronics, robust control for electric vehicles and propulsion systems, power electronics, antilock brake systems, and anti-skid control for electric vehicle drives are among its research interests. Email :_gasbaoui_2009@yahoo.com 

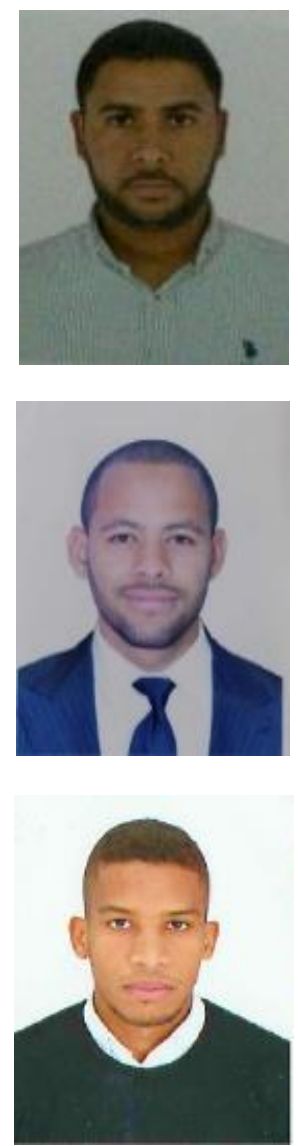

Soumeur mohammed amine, he obtained a B.Sc. in electrical engineering from Tahri Mohamed University in Bechar, Algeria, in 2015, and an M.Sc. in control of electric systems from Tahri Mohamed University in Bechar, Algeria, in 2017. He is now a Ph.D. candidate at Tahri Mohamed University's Smart Grids \& Renewable Energy Laboratory in Bechar, Algeria. Electric vehicles, DC-DC converters, power storage, PVsystems, DTC control, robust control, fuel cells, power electronics, DC micro-grids, and hybrid systems are among his research interests. E-mail : amirehamo@gmail.com

Hafsi Oussama, in 2013 and 2015, he received his B.Sc. in electrical actuator control from Ahmed Draya University in Adrar, Algeria, and his M.Sc. in electrical actuator control from Tahri Mohamed University in Bechar, Algeria. He is currently a PhD student at Tahri Mohamed's Smart Grids and Renewable Energies Laboratory in Bechar, Algeria. DC microgrids, DC-DC converters, renewable energy, control and management systems are among his research interests. E-mail : oussama5bm@gmail.com

Hartani Mohammed amine in 1993, he was born in Beni-Ounif, Bechar, Algeria. In 2015, he graduated from Tahri Mohammed University in Bechar, Algeria, with a degree in electrical engineering. In 2017, he earned a master's degree in electrical machinery control and monitoring from the same university. Now, he is a doctoral student in electrical engineering in collaboration with Ahmed Draya university, adrar, Algeria and Tahri Mohamed university, Bechar, Algeria. his researches focus on the energy management of island and remote areas, integration of renewable energies in dc smart microgrids, autonomous and hybrid systems based on renewable energies and storage devices, optimization methods, classical control strategies and genetic algorithms. E-mail : aminedcgrid17@gmail.com 